bulbar and spinal motor centres are set in action) a voluntary movement can no more take place than can a gun be fired without the pulling of its trigger.

This was the first case of the kind I had had the opportunity of examining after fully realising the consequences of my own views as to the real nature of a case of so-called "hysterical paralysis." It was with much interest therefore that, in the presence of our then senior residentmedical officer, Dr. Taylor, I tested this patient as to her ability to recall in idea movements of her paralysed arm. This ability was found to be absent, as the note then made (April 18th) shows. But such paralysis and inability to recall movements in idea which is found in association with loss of muscular sense in cases of structural or functional disease of the kinæesthetic centres, is not by any means necessarily present in all cases where there is loss of muscular sense. All-important differences are met with according as the loss of muscular sense is dependent upon diseases of a functional or structural type involving the afferent tracts for kinæsthetic impressions; or as it is dependent npon disease involving the cortical centres for such impressions. It is in the latter case only that we have a right to expect as consequences a corresponding motor paralysis, together with an inability to recall corresponding movements in idea. A forgetfulness or failure to recognise this important distinction on the part of several writers has given rise to much confusion. It is the mere afferent channels for these and other sensory impressions that are affected in a great majority of the cases of profound hemianæsthesia, and in them there need be neither the existence of paralysis nor of any inability to recall movements ideally. Still, as a matter of fact, these two groups of symptoms often go together--that is, we may have patients suffering from profound hyperanæsthesia and at the same time from paralysis of the affected limbs. The occurrence of such a combination may, as we shall afterwards see, be accounted for in different ways; but one, and that the most probable, mode of explanation is to suppose that both afferent channels and some portion of their cortical centres are simultaneously affected by the same kind of nutritive depression.

\section{THE INDIAN PILGRIM TRAFFIC.}

By SURG.-GEN. SIR WM. MOORE, K.C.I.E., Q.H.P.

In The LanceT of Sept. 19th last, in the annotation headed "Cholera," the following sentence occurs :- "What is wanted is an adequate provision for, and a systematic application of, sanitary arrangements to the pilgrims" from India to Mecca. The truth of this remark will be apparent when it is known that more than one-third of the pilgrims who leave Bombay on the "Haj" never come back. The following table, recently appearing in the Times of India, shows the number of pilgrims leaving and returning to Bombay during six recent years :-

\begin{tabular}{|c|c|c|c|}
\hline \multirow{2}{*}{ Years. } & \multicolumn{3}{|c|}{ Number of Pilgrms. } \\
\hline & Left. & Returned. & Missing. \\
\hline 1885 & 8,436 & 5,405 & 3,391 \\
\hline 1886 & 8,606 & 6,150 & 2,456 \\
\hline 1887 & 9,466 & 5,726 & 3,740 \\
\hline 1888 & 13,970 & 6,505 & 7,465 \\
\hline 1889 & 12,495 & 10,101 & 2,394 \\
\hline 1890 & 11,665 & 8,662 & 3,003 \\
\hline Total .. ... & 64,638 & 42,189 & $2 ?, 449$ \\
\hline
\end{tabular}

It is of course quite possible that some few may return to India by other routes, and not by the pilgrim ships, but the number so returning must be very small, as alternative routes entail difficult journeys overland through Arabia, Persia, Affghanistan, \&c. Bombay is the port for the pilgrim traffic for the whole of India and for the most considerable portion of that of Central Asia, and much has been done by the Indian authorities towards regulating the pilgrim traffic. A few years back a revised "Pilgrim and Native Passengers Ship Act" was passed. By this Act pilgrims were required to take passports. Ships carrying pilgrims were obliged not only to have bills of health at Bombay, but also to submit to inspection at Aden; also to have improved cooking, washing, and latrine arrangements. Each vessel carries a medical officer, who, although not a Government medical officer, is approved by the SurgeonGeneral of the Indian Medical Department. Vessels from the Persian Gulf touching at Indian ports are also required to submit to inspection. Notwithstanding all this, however, the mortality among the pilgrims is very large, for those not returning in the pilgrim ships to Bombay are, with few exceptions, dead. Dr. Mac Cartie, the port surgeon of Bombay, has recently recommended an increase of the accommodation in pilgrim ships from 9 to 12 superficial feet, and from 54 to 72 cubic feet per adult during the fair season, and in the monsoon to 15 and 90 feet. Doubtless uch accommodation should be provided at sea, even for natives of India. But it is questionable if such increase would very much diminish the mortality, for the greatest number of deaths occurring on board ship al ways takes place during the return voyage, when the ships carry fewer passengers than on the outward voyage. Also, the mortality is always greatest during a monsoon return voyage. In fair weather a large number of the pilgrims locate them. selves on deck, and remain there day and night. But when they are compelled to go below by falling rain, and encroaching seas, the aeath-rate invariably rises, and this especially on the return passage. Various other factors also conduce to a large mortality among the pilgrims. A large proportion of those proceeding to Mecca are old or infirm. They proceed when they can, and do not limit the "Haj" to the fair season. Many are impecunious, and therefore fare badly. Neither have they clothing sufficient to protect them from the atmospheric changes they must encounter. No doubt the sanitary arrangements under which they sail are susceptible of further improvement. But the principal reasons of the mortality are the life they lead at Mecca-often wanting suitable food, water, clothing, and shelter-and the other insanitary conditions under which they are placed. And this notwithstanding certain improvements during recent years at Mecca and Medina. The matter is one of great interest, and demands earnest attention. But whatever the Indian authorities may accomplish, there will always be much sickness and mortality so long as sanitary conditions are so indifferent at the ports and places to which pilgrims resort.

That large assemblies of pilgrims may form and disperse without the occurrence of any epidemic, if under suitable sanitary supervision, has been abundantly demonstrated at Indian fairs and festivals. And this even when cholera has prevailed in the neighbouring districts. To various examples which might be named may be added the immunity of the pilgrims from disease at the late great fair at Hurdwar, on the "Khumb Mela" of 1891. Formerly, it might truthfully be said of an Indian fair, or festival, cholera will be there; now it can be said cholera will most probably not occur. I will not detail the various sanitary arrangements now enforced at Indian shrines which have conduced to this. result. But I feel sure that if similar arrangements were adopted at places of pilgrimage out of India, the sickness and mortality of the pilgrims would be very greatly reduced. For, as before stated, it is during the return vovage that the greatest mortality happens on board ship. This is not so much cansed by sea life, as by the condition into which the pilgrims fall during their stay at the shrine, before they essay the return journey.

\section{CASE OF EXCISION OF A LARGE SPINA} BIFIDA.

By H. H. CLUTTON, F.R.C.S. Eng. \&c.

THIs case is of interest from the age of the patient at the time the operation was performed, from the large size of the tumour, and the freedom from all symptoms which could cause anxiety. Evidence from all sides is accumu. lating to show that the spinal membranes may be opened and continue to discharge large quantities of cerebro-spinal fluid for some days without producing any serious sym. 